\title{
CONTROL OF ENVIRONMENTAL PARAMETERS FOR MANAGEMENT AND CONSERVATION OF NERJA CAVE (MALAGA, SPAIN)
}

\author{
PREGLED OKOLJSKIH PARAMETROV PRI VODENJU IN \\ VAROVANJU JAME NERJA (MÁLAGA, ŠPANIJA)
}

FRANCISCO CARRASCO ${ }^{1} \&$ IÑAKI VADILLO ${ }^{1} \&$ CRISTINA LIÑÁN ${ }^{2} \&$ BARTOLOMÉ ANDREO ${ }^{1} \&$ JUAN JOSÉ DURÁN ${ }^{3}$

${ }^{1}$ Department of Geology. Faculty of Science. University of Malaga. 29071 MALAGA, SPAIN, e-mails: fcarrasco@uma.es,vadillo@uma.es, andreo@uma.es

${ }^{2}$ Nerja Cave Foundation. Carretera de Maro s/n. 29787 NERJA, MALAGA, SPAIN, e-mail: baena@vnet.es

${ }^{3}$ Instituto Geológico y Minero de España. C/ Ríos Rosas, 23. 28003 MADRID, SPAIN, e-mail: jj.duran@igme.es 


\section{Francisco Carrasco \& Iñaki Vadillo \& Cristina Liñán \& Bartolomé Andreo \& Juan José Durán: Pregled okoljskih parametrov pri vodenju in varovanju jame Nerja (Málaga, Španija)}

V povprečju obišče jamo Nerja več kot 500.000 ljudi letno. Od leta 1993 je v jami instalirana mreža monitoringa, ki vsako uro meri številne parametre, da bi ugotovili vplive obiskovalcev na podzemno okolje. Od 1991 izvršujejo hidrokemične meritve vode v curkih $\mathrm{v}$ jami in pri naravnih iztokih iz karbonatnega vodonosnika. Zvezna merjenja fizikalno kemijskih parametrov prenikajoče vode, dnevni odtok, kakor tudi temperatura in relativna vlažnost zraka, koncentracija $\mathrm{CO}_{2}$ in temperatura skale kažejo človekov vpliv. Glavne spremembe okoljskih parametrov so naslednje: 1 . zračna temperatura zraste za $0,2{ }^{\circ} \mathrm{C}$ na vsakih 1000 obiskovalcev na dan; 2. relativni porast relativne zračne vlage med 2 in $3 \%$, ki v poletnih dneh doseže nasičenost; 3. koncentracija $\mathrm{CO}_{2}$ v zraku narase do vrednosti med 500 in $700 \mathrm{ppm}$ v obdobju manjšega obiska in za desetkratno izhodiščno vrednost ob času velikega obiska $(2.800 \mathrm{ppm})$; 4. temperatura skale narase med $0,02{ }^{\circ} \mathrm{C}$ do $0,15^{\circ} \mathrm{C}$ na dan in $5 . \mathrm{P}_{\mathrm{CO} 2}$ prenikajoče vode izkazuje spremembe, naraščajoče med velikim obiskom in padajoči indeks nasičenosti karbonatnih mineralov.

Ključne besede: jama Nerja, človekov vpliv, okoljski parametri, hidrokemija, varovanje.

\section{Abstract \\ UDC: 504.05:551.44(60) \\ Francisco Carrasco \& Iñaki Vadillo \& Cristina Liñán \& Bartolomé Andreo \& Juan José Durán: Control of environmental parameters for management and conservation of Nerja Cave (Malaga, Spain)}

The Nerja Cave receives on average more than 500,000 visitors per year. In order to know the possible impact in the underground environment by human visits, a monitoring network was installed since 1993, to control hourly several parameters. Also, since 1991 a hydrochemical control has been carried out in the drip water points of the cave and in the natural discharge points of the carbonate aquifer. This continuous record of physical-chemical parameters of drip water, its daily outflow, as well as temperature and relative humidity in the air, $\mathrm{CO}_{2}$ concentration and rock temperature shows the human influence. The main changes in environmental parameters are the following: 1 . cave air temperature rises $0.2^{\circ} \mathrm{C}$ by 1000 visitors/day; 2 . a daily increase between 2 and $3 \%$ in relative air humidity, reaching saturation on summer days; $3 . \mathrm{CO}_{2}$ concentration in air increases up to values between 500 and $700 \mathrm{ppm}$ during low visitability periods and 10 times the background value during high visitability periods $(2.800 \mathrm{ppm})$; 4 . temperature of the rock rises between 0.02 ${ }^{\circ} \mathrm{C}$ and $0.15{ }^{\circ} \mathrm{C} /$ day, and (5) $\mathrm{P}_{\mathrm{CO} 2}$ of drip water also presents variations, increasing during the big influx of visits and decreasing the saturation index of carbonated minerals.

Key words: Nerja Cave, anthropic influence, environmental parameters, hydrochemistry, conservation. 


\section{INTRODUCTION}

Karstic cavities are domains which have been traditionally studied from a speleological or scientific approach (Trombe 1952) but in the last few years the interest has become economic (Mangin \& D'Hulst 1995; Huppert et al. 1993). Everyday, there are many cavities visited by the public that constitute important economic activities in the region where they are situated. Visits produce an impacts in the underground environment: variations of the climatic parameters (temperature, humidity and $\mathrm{CO}_{2}$ ), contamination and changes of the physic-chemical parameters of the groundwater and rock alteration. Microflora (algae, principally) also appears at places in the cavities where light and water coexist. These problems have been identified in several caves, i.e.: Altamira Cave (Fernández et al. 1986), Grande del Vento Cave (Bertolani et al. 1991), PechMerle Cave (Mangin et al. 1991), Nerja Cave (Carrasco et al. 1995, 1999), Maravillas Cave (Pulido et al. 1997) and Gargas Cave (Mangin et al. 1999), among others. The anthropic impact on the underground environment is an interesting line of research; it is necessary to regulate the visits to the caves for an adequate explotation and management of this resource (Cigna 1993).

This work illustrates the human impact on the environmental parameters and on the drip water in the Nerja Cave, a tourist cave situated in the south of Spain (Andalusia), $50 \mathrm{~km}$ to the east of Malaga city and less than $1 \mathrm{~km}$ from the Mediterranean sea (Fig. 1A).

The cave extends almost $5 \mathrm{~km}$ in chambers and galleries with a difference between the lowest and highest points of $70 \mathrm{~m}$ and a volume of $300,000 \mathrm{~m}^{3}$. The cave is practically horizontal and covers an approximate surface of $140,000 \mathrm{~m}^{2}, 700 \mathrm{~m}$ in length and $200 \mathrm{~m}$ in width. The largest galleries are mainly oriented N35E in the southern area and N-S in the northern area, which coincides with the principal fracturation lines. The cave entrance is situated at an elevation of $158 \mathrm{~m}$.

It was discovered in 1959 and was opened to the public the following year. Since then, it has been a very visited natural attraction in Spain, with more than 500,000 visitor per year. Its popularity is influenced by its location in a major tourist zone (Costa del Sol) and by the beauty of the chambers and speleothems that can be found there. Two parts can be distinguished in the cave (Fig. 1B): the tourist area, restricted to a one-third of the cave nearest the entrance, and the nontouristic area, which is made up of the other two-thirds of the cavity, only visited by occasional groups of researchers, speleologists and by speleotourists.

\section{GEOLOGICAL AND HYDROGEOLOGICAL SETTINGS}

From a geological standpoint, the cave is situated in the Almijara unit, belonging to the Alpujarride complex of the Internal Zone of the Betic Cordillera (Sanz de Galdeano 1986; Andreo et al. 1993). This complex has two lithological formations (Fig. 1A): a lower formation, made up of metapelites of Paleozoic age and an upper one made up of carbonate rocks of middle-upper Triassic. At the base of this latter formation outcrop white dolomitic marbles whilst at its top appears blue calcareous marbles. The cave is developed in the dolomitic marbles which are highly fractured. In some places, this rock is completely shattered, giving rise to a typical sugar texture, with grains made up of single dolomite crystals. Outside the cave, detrital Neogene deposits outcrop discordantly over the Alpujarride rocks (Fig. 1A). 
Although the structure of the Alpujarride complex is very complicated on a regional scale, in the surroundings of the cave is quite simple because the marbles have an almost tabular structure, dipping $15-20^{\circ}$ towards the south (Andreo et al. 1993). Marbles are limited to the south by normal and strike-slip faults, which have caused significant vertical movements since Pliocene.

Karst landforms (karren, dolines, sinkholes) hardly exist in these carbonate rocks but on the other hand, there is a well-developed superficial drainage system, favoured by the considerable slopes of the Almijara mountain, as well as the texture of the dolomitic marbles (Benavente \& Almécija 1993). Karst cavities are rare in the Alpujarride carbonate aquifer; so Nerja Cave is a major exception. The karstification process which gave rise to this cave occurred throughout the

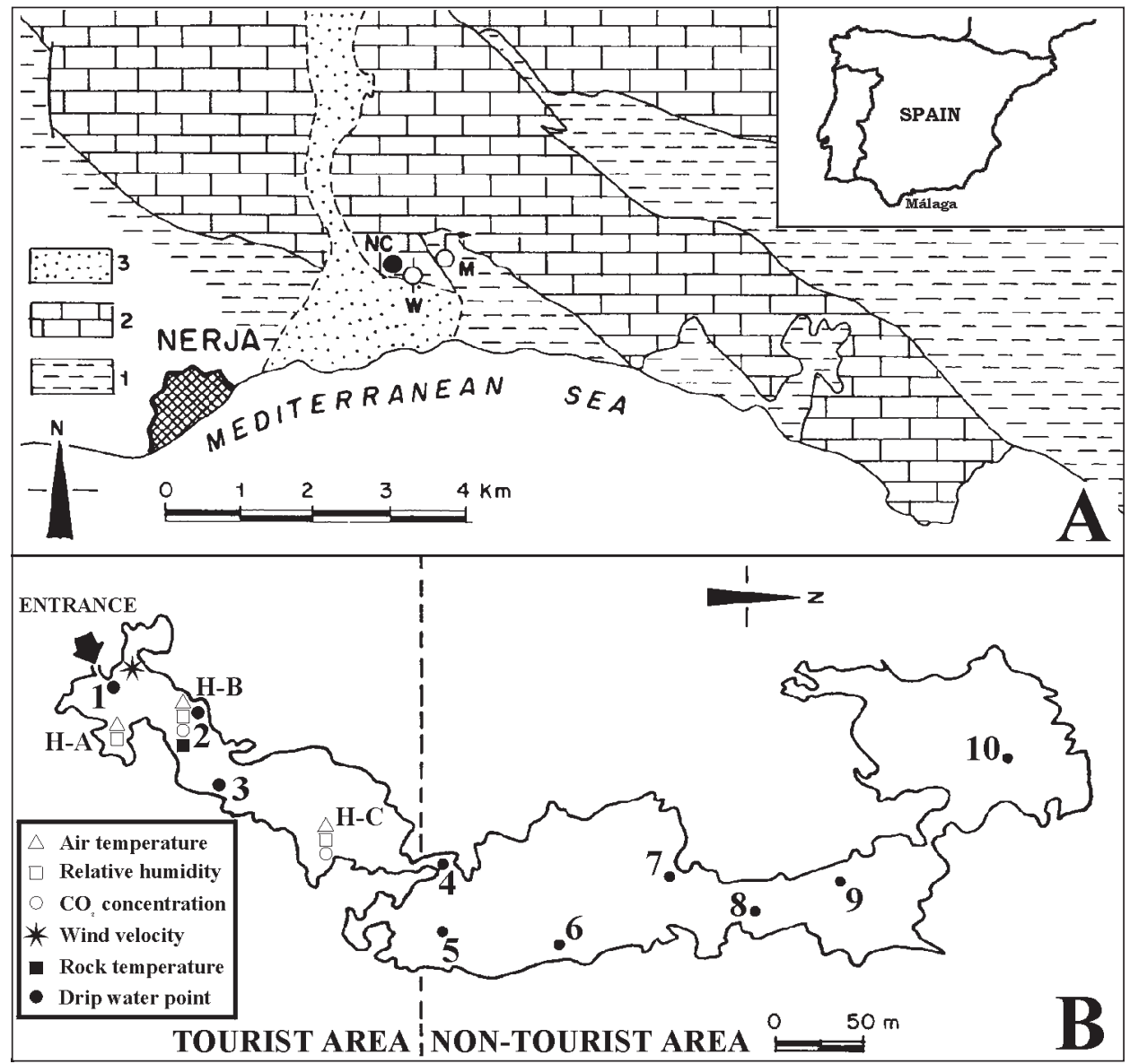

Fig. 1: Situation and geological sketch of the Nerja Cave (modified from Carrasco et al. 1995). A: 1, metapelites; 2, marbles; 3, Pliocene and Quaternary deposits; NC, Nerja Cave entrance; $M$, Maro spring; $W$, well. B: location of the sensors (Halls A, B and C) and drip water sampling points in the cave. 
Pliocene and the Pleistocene. During the temperate and hot periods of the Quaternary age enormous quantities of calcite or aragonite deposits were generated (Durán et al. 1993).

The Triassic marbles outcroping in Sierra Almijara constitute an aquifer of regional importance (IGME 1983; SGOP 1991, Andreo \& Carrasco 1993a), which recharge is produced mainly by infiltration of rainwater. The aquifer discharge, apart from wells, is produced by a series of springs, with Maro spring as the most important one. This spring is situated less than $1 \mathrm{~km}$ to the east of the cave (Fig. 1A), at an elevation of $120 \mathrm{~m}$. The outflow of the spring varies between 20 1/s and 1600 1/s, with a mean value of 250 1/s. The Maro spring has a typical karstic behaviour because it responds very quickly to rainwater with a increasing outflow and dilution of the chemical composition of the water (Andreo \& Carrasco 1993a; Carrasco et al. 1996; Liñán et al. 2000).

The cave is actually in the vadose zone of the aquifer, several metres above the water table, because of sea-level changes and neotectonic activity of faults limiting the aquifer to the south.

\section{CLIMATIC CHARACTERISTICS OF THE STUDY AREA}

The average rain water in the two closer meteorological stations, during the period 1969 to 1992, has been 463 and $517 \mathrm{~mm}$ per year, respectively. So the average rain water over the Nerja Cave system could be estimated at $500 \mathrm{~mm}$ per year, though this value varies between 250 and $800 \mathrm{~mm}$ per year. The temporal distribution of the average monthly rainfall, throughout a hydro-

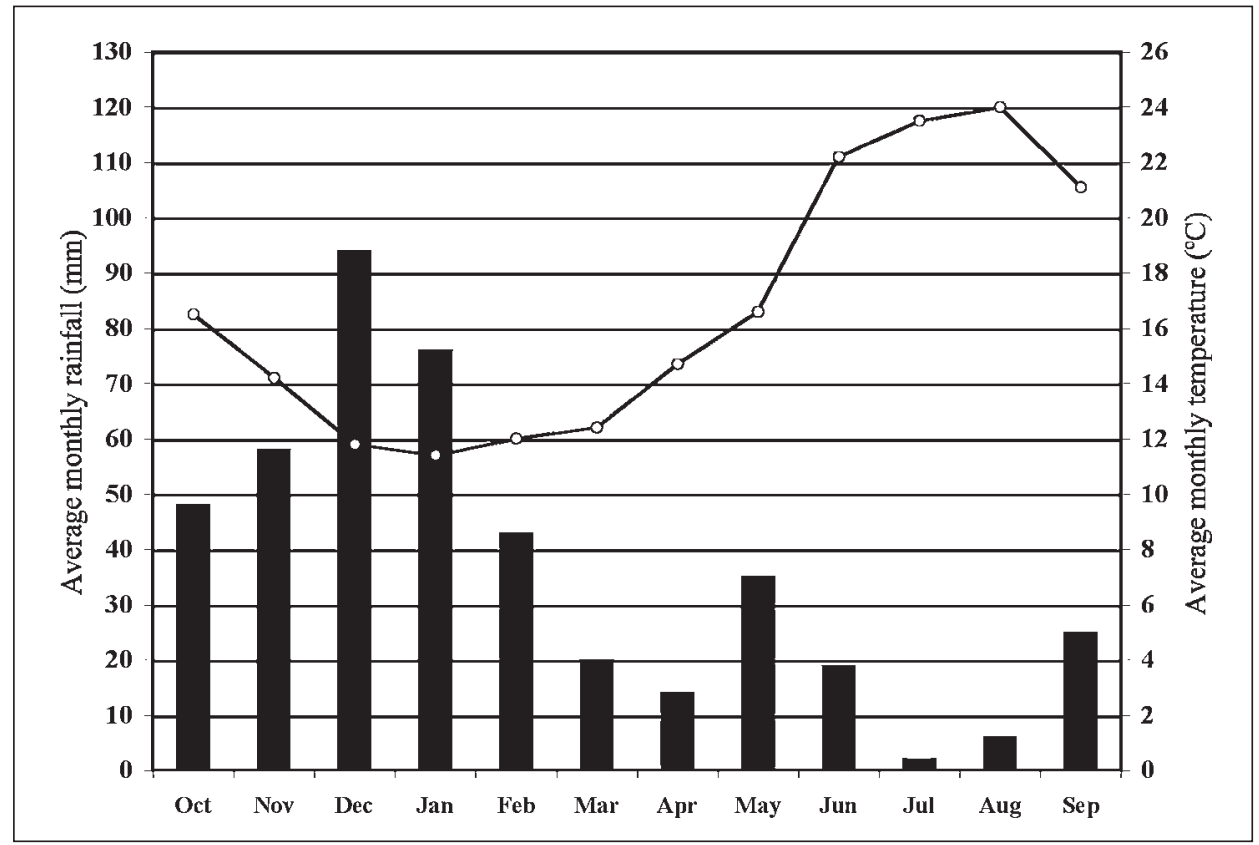

Fig. 2: Average values of monthly precipitation (columns) and temperatures (line) in Nerja city station for the period 1969-1992. 
logical year, has a decreasing trend from the months with major precipitation (November to January) to the dry months (July and August), with a relative maximum in May (Fig. 2). The average annual temperature in the nearest meteorological station of Nerja city is $16.5^{\circ} \mathrm{C}$, with a maximum value in August $\left(24.0^{\circ} \mathrm{C}\right)$ and minimum in January $\left(11.4^{\circ} \mathrm{C}\right)$.

Table 2: Statistical summary of the physical-chemical data registered in the monitoring network.

\begin{tabular}{|c|c|c|c|c|c|c|c|c|c|c|c|c|c|}
\hline & Point & E.C. & $\mathrm{Ca}^{2+}$ & $\mathrm{Mg}^{2+}$ & $\mathrm{Na}^{+}$ & $\mathrm{K}^{+}$ & $\mathrm{Cl}^{-}$ & $\mathrm{SO}_{4}{ }^{2-}$ & AlK. & $\mathrm{NO}_{3}^{-}$ & $\mathrm{SiO}_{2}$ & $\mathrm{P}_{\mathrm{CO} 2}$ & SIc \\
\hline $\mathrm{n}$ & $P$ & 251 & 74 & 72 & 125 & 125 & 111 & 47 & 80 & 103 & 78 & 14 & 13 \\
\hline w.m. & & 49 & 3,5 & 2,5 & 4,6 & 2,8 & 10,7 & 11,8 & 18,9 & 1,8 & 3,6 & 0,26 & $-2,98$ \\
\hline $\mathrm{v}(\%)$ & & 100 & 145,9 & 89,4 & 127,6 & 242,7 & 78,3 & 96,2 & 97,7 & 276,2 & 387,2 & 143,02 & $-22,89$ \\
\hline $\mathrm{n}$ & 1 & 117 & 67 & 67 & 67 & 67 & 67 & 66 & 67 & 67 & 65 & 66 & 66 \\
\hline $\mathrm{m}$ & & 1126 & 135,9 & 65,3 & 32,6 & 2,3 & 83,8 & 296,5 & 371,8 & 18,2 & 14,8 & 0,43 & 0,86 \\
\hline $\mathrm{v}(\%)$ & & 9 & 14,7 & 17,5 & 31,5 & 147,7 & 19,1 & 14,5 & 9,3 & 73,5 & 13,5 & 43,17 & 19,31 \\
\hline $\mathrm{n}$ & 2 & 13 & 14 & 14 & 14 & 14 & 14 & 14 & 14 & 14 & 14 & 13 & 13 \\
\hline $\mathrm{m}$ & & 531 & 41,4 & 41,6 & 7,7 & 2,2 & 25,1 & 14,7 & 300,0 & 2,3 & 7,2 & 0,13 & 0,85 \\
\hline $\mathrm{v}(\%)$ & & 11 & 28,9 & 15,3 & 18,8 & 121,1 & 19,0 & 24,0 & 13,7 & 39,4 & 16,0 & 71,24 & 30,35 \\
\hline $\mathrm{n}$ & 3 & 270 & 273 & 272 & 244 & 244 & 239 & 223 & 277 & 187 & 173 & 229 & 228 \\
\hline $\mathrm{m}$ & & 459 & 29,5 & 44,7 & 9,6 & 3,7 & 24,5 & 18,6 & 285,4 & 3,3 & 9,2 & 0,14 & 0,60 \\
\hline $\mathrm{v}(\%)$ & & 11 & 28,3 & 9,8 & 31,6 & 222,3 & 53,2 & 84,8 & 8,7 & 95,1 & 44,4 & 75,45 & 35,08 \\
\hline $\mathrm{n}$ & 4 & 17 & 17 & 17 & 17 & 17 & 17 & 17 & 17 & 17 & 17 & 17 & 17 \\
\hline $\mathrm{m}$ & & 529 & 44,9 & 42,3 & 8,5 & 2,8 & 29,7 & 17,4 & 304,8 & 6,1 & 10,8 & 0,18 & 0,85 \\
\hline $\mathrm{v}(\%)$ & & 5 & 16,4 & 11,1 & 9,0 & 168,2 & 14,5 & 14,9 & 6,2 & 26,9 & 11,7 & 133,88 & 30,76 \\
\hline $\mathrm{n}$ & 5 & 8 & 8 & 8 & 8 & 8 & 8 & 8 & 8 & 8 & 8 & 8 & 8 \\
\hline $\mathrm{m}$ & & 522 & 40,1 & 42,9 & 9,4 & 1,1 & 32,8 & 21,0 & 298,0 & 3,7 & 8,6 & 0,08 & 0,95 \\
\hline $\mathrm{v}(\%)$ & & 4 & 16,7 & 7,3 & 9,5 & 67,9 & 1,9 & 12,9 & 2,4 & 55,9 & 22,2 & 24,57 & 7,21 \\
\hline $\mathrm{n}$ & 6 & 15 & 14 & 14 & 14 & 14 & 14 & 14 & 14 & 14 & 14 & 14 & 14 \\
\hline $\mathrm{m}$ & & 504 & 48,3 & 40,3 & 5,8 & 1,7 & 21,2 & 11,0 & 317,8 & 8,9 & 8,6 & 0,13 & 0,93 \\
\hline v (\%) & & 9 & 23,9 & 13,6 & 8,5 & 84,8 & 13,0 & 27,0 & 7,5 & 37,3 & 25,1 & 37,86 & 16,10 \\
\hline $\mathrm{n}$ & 7 & 60 & 60 & 60 & 60 & 60 & 60 & 59 & 60 & 60 & 60 & 59 & 59 \\
\hline $\mathrm{m}$ & & 472 & 41,9 & 36,7 & 6,3 & 3,2 & 27,3 & 19,4 & 277,2 & 5,5 & 7,5 & 0,14 & 0,76 \\
\hline $\mathrm{v}(\%)$ & & 18 & 16,3 & 19,4 & 22,6 & 413,5 & 82,4 & 36,8 & 5,7 & 83,3 & 17,4 & 58,92 & 25,74 \\
\hline $\mathrm{n}$ & 8 & 14 & 14 & 14 & 14 & 14 & 14 & 14 & 14 & 14 & 14 & 14 & 14 \\
\hline $\mathrm{m}$ & & 392 & 19,0 & 42,5 & 8,4 & 2,3 & 26,6 & 16,2 & 233,2 & 3,1 & 9,5 & 0,05 & 0,70 \\
\hline v (\%) & & 11 & 18,1 & 5,3 & 7,7 & 147,5 & 12,5 & 16,3 & 2,9 & 20,6 & 10,3 & 32,26 & 13,17 \\
\hline $\mathrm{n}$ & 9 & 10 & 10 & 10 & 10 & 10 & 10 & 10 & 10 & 10 & 10 & 10 & 10 \\
\hline $\mathrm{m}$ & & 418 & 22,3 & 42,8 & 6,9 & 3,1 & 26,9 & 13,5 & 251,2 & 2,4 & 7,2 & 0,06 & 0,71 \\
\hline $\mathrm{v}(\%)$ & & 6 & 13,0 & 3,2 & 13,3 & 140,7 & 13,5 & 26,8 & 3,9 & 25,0 & 15,8 & 18,57 & 11,31 \\
\hline $\mathrm{n}$ & 10 & 11 & 10 & 10 & 10 & 10 & 10 & 10 & 10 & 10 & 10 & 10 & 10 \\
\hline $\mathrm{m}$ & & 483 & 44,0 & 38,5 & 5,5 & 1,3 & 20,6 & 13,7 & 304,7 & 2,2 & 7,1 & 0,10 & 0,95 \\
\hline $\mathrm{v}(\%)$ & & 7 & 13,0 & 6,8 & 18,2 & 84,6 & 4,5 & 27,8 & 7,3 & 40,1 & 11,5 & 26,60 & 4,43 \\
\hline $\mathrm{n}$ & M & 180 & 102 & 102 & 73 & 73 & 73 & 73 & 100 & 69 & 69 & 70 & 69 \\
\hline $\mathrm{m}$ & & 648 & 99,0 & 24,0 & 8,8 & 1,9 & 24,0 & 182,7 & 209,1 & 0,6 & 15,1 & 0,41 & 0,33 \\
\hline $\mathrm{v}(\%)$ & & 15 & 21,2 & 52,7 & 37,1 & 26,0 & 31,8 & 39,2 & 9,0 & 100,9 & 57,2 & 42,23 & 77,37 \\
\hline $\mathrm{n}$ & W & 76 & 41 & 41 & 40 & 40 & 40 & 38 & 41 & 39 & 38 & 39 & 39 \\
\hline $\mathrm{m}$ & & 674 & 79,7 & 33,6 & 14,3 & 2,8 & 33,6 & 90,7 & 294,0 & 12,1 & 13,8 & 1,05 & 0,20 \\
\hline $\mathrm{v}(\%)$ & & 9 & 11,8 & 22,1 & 28,2 & 42,4 & 15,5 & 17,4 & 10,7 & 63,6 & 80,7 & 39,93 & 117,88 \\
\hline
\end{tabular}

Legend. P: rainfall; $n$ : number of measurements; $m$ : average; w.m: weighted average; $v$ : coefficient of variation. All chemical contest in $\mathrm{mg} / \mathrm{l}, P_{\mathrm{CO} 2}$ in atm $\times 10^{-2}$ and E.C. in $\mu \mathrm{S} / \mathrm{cm}$ at $25^{\circ} \mathrm{C}$. 
In 1991 a meteorological station was installed outside the cave, for rainfall and temperature recording and for chemical and isotopic monitoring. During the last ten years (1991-2001) the average rainfall over the cave has been $445 \mathrm{~mm}$ per year. The minimum value was $145 \mathrm{~mm}$ in the hydrological year 1994/95, coinciding with a drought period in southern Spain, and the maximum value was $819 \mathrm{~mm}$ in 1996/97.

Rain water in the meteorological the cave station has a hydrochemical facies ranged from sodium-chloride to calcium-bicarbonate, a slightly acid pH (6.06 as mean value) and an average electrical conductivity of $49 \mu \mathrm{S} / \mathrm{cm}$ (Table 2), which varies between 12 and $443 \mu \mathrm{S} / \mathrm{cm}$, being higher when the amount of rainfall decreases. In certain rainy periods water shows high $\mathrm{K}^{+}$content (up to $50 \mathrm{mg} / \mathrm{l}$ ) and $\mathrm{Cl}^{-}$(up to $60 \mathrm{mg} / \mathrm{l}$ ), according to Carrasco et al. $(1996,1999)$ and Liñán et al. (1999).

\section{NUMBER OF VISITORS GOING INTO THE CAVE}

The average flux of visits to the cave is 560,000 visitors per year throughout the period between 1988-2001 (Fig. 3A). The monthly distribution (Fig. 3B) is very similar for different years, with a minimum number of visitors in January-February and November-December (between 9,000-33,000 visitors/month) and a maximum number in August (between 83,000-119,000 visitors/month). The number of visitors can vary daily between 200 and 3,500 persons; some days reaching up to 5,000 persons.

The curve of the monthly average number of visitors for the same period (Fig. 3C) shows an asymetric bell-shaped morphology, with maximum in August (103,286 visitors) and minimum in January (15,582 visitors).

All underground parameters suffer an impact when cave is opened to the public. This environmental impact depends mainly, on external factors as (1) number of visits and (2) its duration, and inherent factors to the cave, i.e. (3) cave volume and (4) natural capacity of ventilation. The duration of the cave visit is estimated in one hour, and during this time, one person contributes with 60 calories and 40 grams of water vapour, and exhales around 20 litres of $\mathrm{CO}_{2}$ (Marion 1985; Andrieux 1988). So, the human presence in the cave provokes an increase of temperature, humidity and $\mathrm{CO}_{2}$. All these factors are characteristics of underground environment, specially $\mathrm{CO}_{2}$ because of its influence in the processes of $\mathrm{CaCO}_{3}$ dissolution and precipitation.

\section{ANTHROPIC INFLUENCE ON THE ENVIRONMENT OF THE CAVE}

\section{Monitoring point}

After the discovery of the cave in 1959 some modifications were made for tourist habilitation in the external third part of the cave. These modifications have carried out several changes both inside and outside the cave: an artificial entrance, the lighting of the halls, habilitation of tourist routes and one permanent area to celebrate the Nerja Cave music festivals. All these modifications, together with the high number of visits produce significant changes in the karst environment. For knowing and studying these changes, a monitoring network system was installed in 1993 (Fig. 1B), that records hourly environmental parameters outside and inside the cave. Outside, the choosen parameters were temperature, relative humidity, $\mathrm{CO}_{2}$ concentration and atmos- 
pheric pressure. Inside the cave there are several types of devices (Fig. 1B):

- Sensor in the entrance to count the number of visitors.

- Sensor of temperature and relative humidity, in hall-A.

- Sensors of temperature and relative humidity of air, temperature of the rock, atmospheric pressure, $\mathrm{CO}_{2}$ concentration and velocity of wind in hall-B.

- Sensors of temperature and relative humidity of air, and $\mathrm{CO}_{2}$ concentration in hall-C.
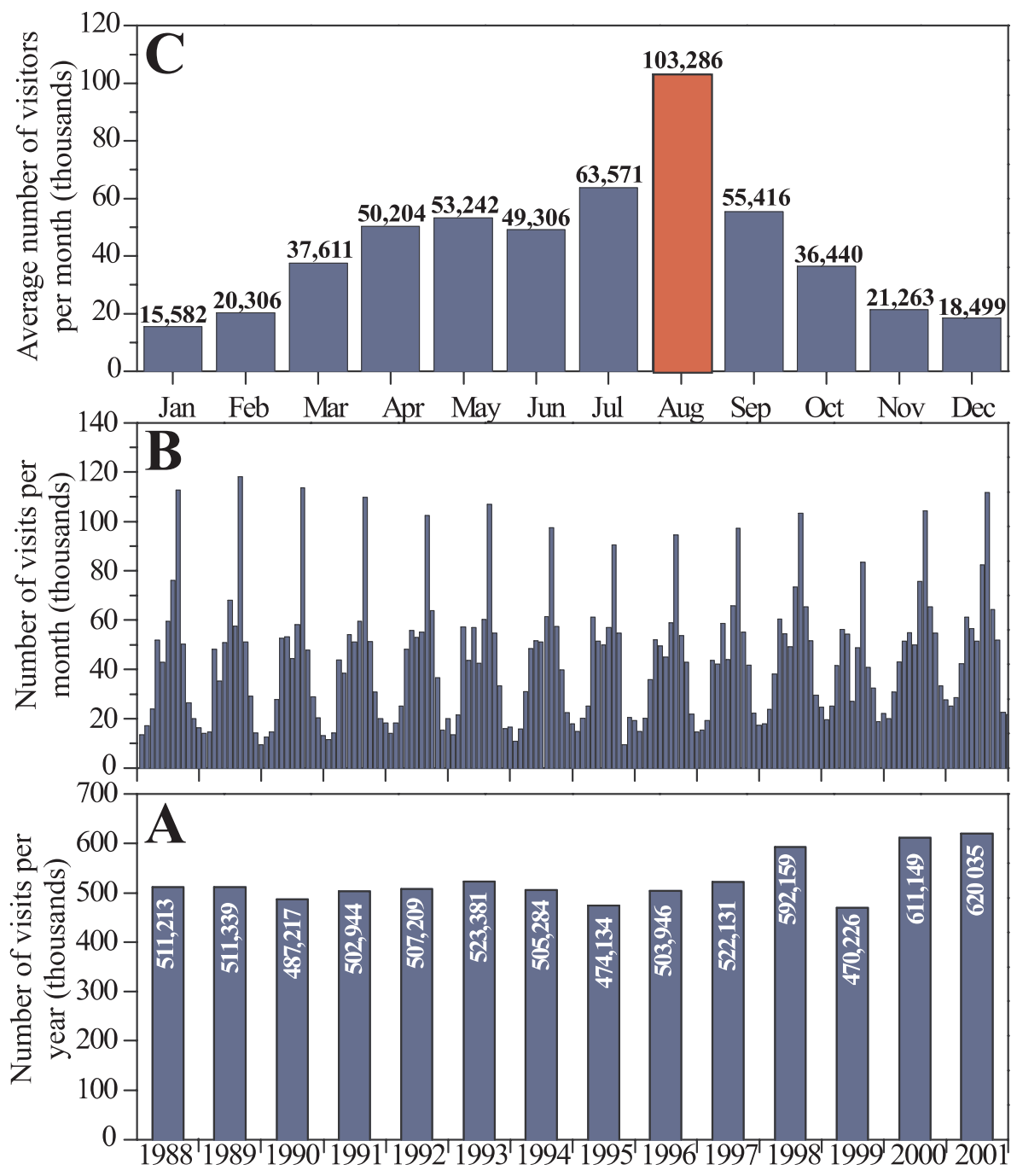

Fig. 3: Visits of Nerja Cave for the period 1988-2001. 
Although the frequency of recorded measurements is hourly, it is very useful for a better understanding of overall processes, to plot them in a yearly scale. For this reason we show daily data of several parameters recorded during year 2001 (Fig. 4), averaging the hourly data recorded

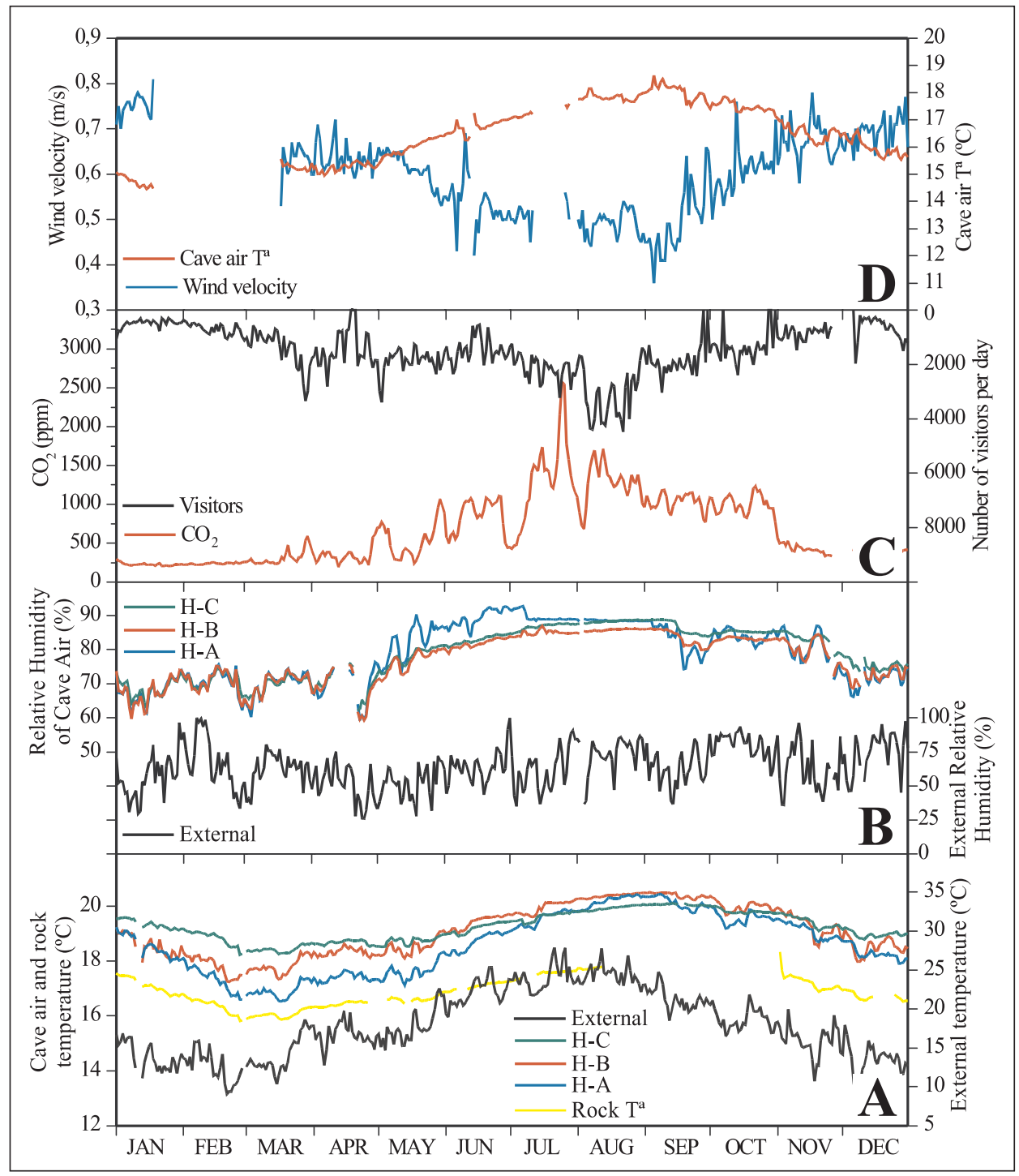

Fig. 4: Annual evolution of daily data (obtained from average of hourly data) for environmental parameters during year 2001. A: Temporal evolution of temperatures (air, rock and outside); $B$ : Relative humidity inside and outside the cave; $\mathrm{C}$ : $\mathrm{CO}_{2}$ in hall $\mathrm{B}$ and number of visitors and D: Velocity of the wind and air temperature. 
in each sensor. A statistical summary of the whole temporal series of data (since 1993 to 2001) is exposed in Table 1.

\section{Temperature of the cave air}

All temperatures inside the cave follows the same wave pattern than the external one, although a delay between outer and inner temperature exists. Whilst external temperature reach its maximum at the end of July-beginning of August and its minimum at the end of February (Fig. $4 \mathrm{~A}$ ), inside the heat transfer to the cave is produced with a delay of approximately one month.

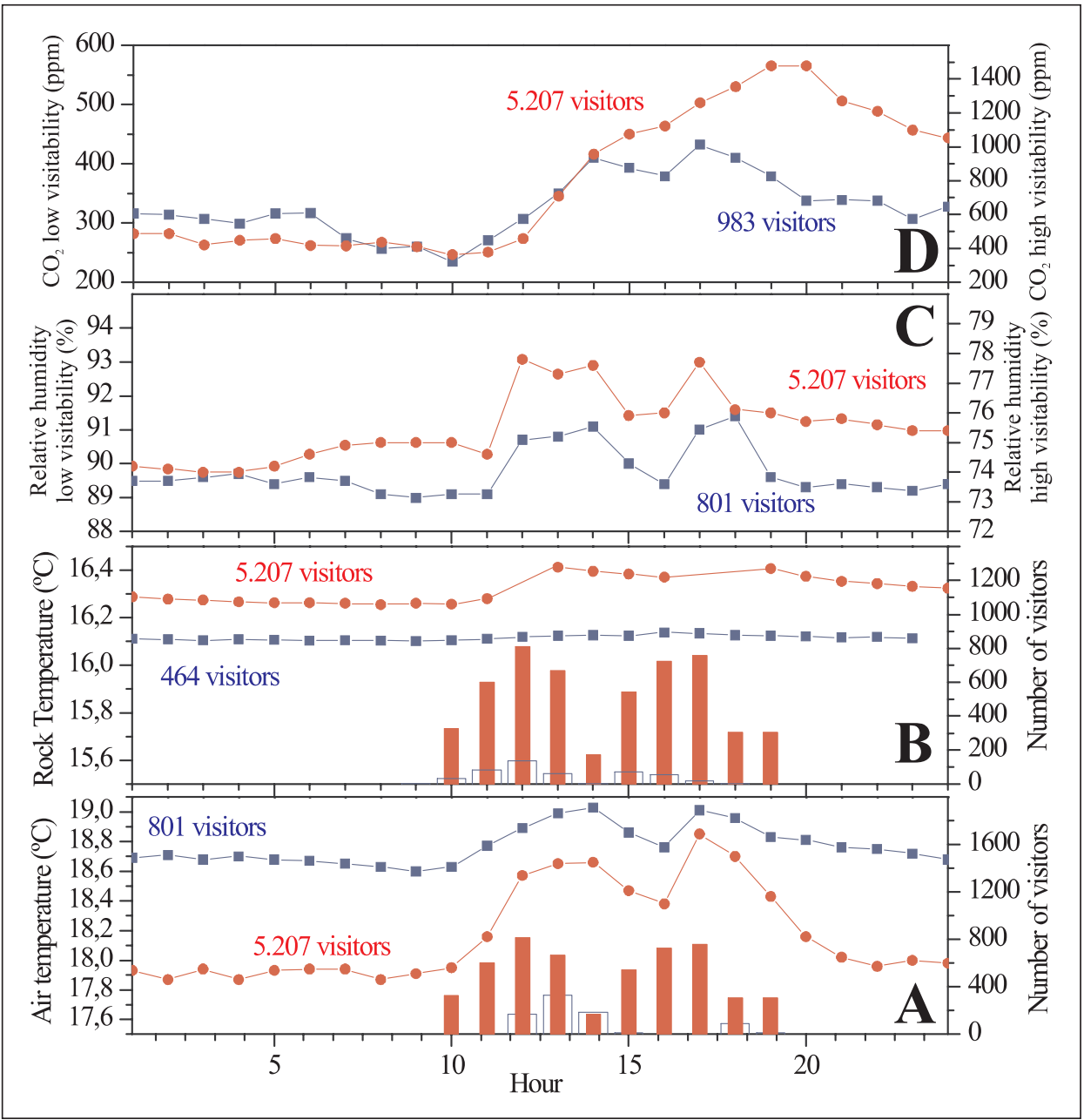

Fig. 5: Hourly comparison between high and low visitability periods for environmental parameters in Nerja Cave. A: Air temperature; $B$ : Rock temperature; $C$ : Relative humidity and D: $\mathrm{CO}_{2}$ concetration in air. 
Cave air temperature increases from halls $\mathrm{H}-\mathrm{A}$ to $\mathrm{H}-\mathrm{C}$, except during summer months, when the higher external temperature creates an inversion of thermal gradient (Fig. 4A). The maximum range in temperatures between halls is reached during spring time with almost $1.5^{\circ} \mathrm{C}$ (Table 1), although depending on the studied period, i.e. year 2001 , this value reach $2.0^{\circ} \mathrm{C}$ (Fig. $4 \mathrm{~A}$ ).

The average temperatures in the different halls are higher than outside (Table 1). The difference between the mean exterior temperature $\left(17.86^{\circ} \mathrm{C}\right)$ and in the hall $\mathrm{C}\left(19.48^{\circ} \mathrm{C}\right)$ is $1.62^{\circ} \mathrm{C}$.

The temperature inside the cave increases during the period when the cave is opened to the public (Fig. 5A), although is very dependent on the period of the year when is measured. This means that the absolute value of the temperature is not dependent on the number of visits, but on the temperature of the atmosphere. In figure $5 \mathrm{~A}$ is clearly seen that the temperature baseline for the day of high visits $\left(5,207\right.$ persons) is situated around $17.9^{\circ} \mathrm{C}$, and during the day of low visits (801 persons) the baseline is located at $18.7^{\circ} \mathrm{C}$, because both have been selected from different periods of the year. The relative temperature, that is, the increase of temperature from the baseline to the maximum of each day is dependent on the number of visits. This is seen in the same figure $5 \mathrm{~A}$, i.e. the values are $0.4^{\circ} \mathrm{C}$ for the first case ( 801 persons) and $1.0^{\circ} \mathrm{C}$ for the second case (5,207 persons). The main cause for this increasing is the cave lighting and the body heat of visitors (Carrasco et al. 1999). The daily decreasing temperature observed at 15:00 hours (Fig. $5 \mathrm{~A})$ is due to the closure of the cave and turning off of lights.

Table 1: Summary of the values of environmental parameters inside the Nerja Cave from December 1993 to December 2001. Statistical summary made with hourly data from the sensors.

\begin{tabular}{|c|c|c|c|c|c|c|c|c|}
\hline & \multicolumn{4}{|c|}{ Temperature $\left({ }^{\circ} \mathrm{C}\right)$} & \multicolumn{4}{|c|}{ Relative Humidity (\%) } \\
\hline & External & A Hall & B Hall & C Hall & External & A Hall & B Hall & C Hall \\
\hline $\mathrm{n}$ & 2638 & 2825 & 2778 & 2646 & 2625 & 2816 & 2813 & 2652 \\
\hline Maximun & 33,59 & 22,79 & 21,54 & 22,98 & 100,00 & 100,00 & 100,00 & 99,78 \\
\hline Minimun & 7,07 & 14,89 & 15,08 & 17,43 & 6,72 & 34,52 & 41,53 & 49,23 \\
\hline Average & 17,86 & 18,59 & 19,04 & 19,48 & 63,34 & 78,03 & 80,17 & 82,68 \\
\hline $\mathrm{v}(\%)$ & 26,77 & 7,82 & 6,02 & 5,99 & 25,86 & 18,06 & 14,27 & 10,50 \\
\hline \multirow[t]{3}{*}{ Range } & 26,52 & 7,91 & 6,46 & 5,55 & 93,28 & 65,48 & 58,47 & 50,55 \\
\hline & \multicolumn{3}{|c|}{$\mathrm{CO}_{2}(\mathrm{ppm})$} & $\begin{array}{c}\text { Rock T } \\
\left({ }^{\circ} \mathrm{C}\right)\end{array}$ & \multicolumn{2}{|c|}{ Pressure } & \multirow{2}{*}{$\begin{array}{c}\text { Number of } \\
\text { visitors per } \\
\text { day }\end{array}$} & \multirow{2}{*}{$\begin{array}{c}\text { Wind } \\
\text { velocity } \\
(\mathrm{m} / \mathrm{s})\end{array}$} \\
\hline & External & B Hall & C Hall & B Hall & External & B Hall & & \\
\hline $\mathrm{n}$ & 373 & 1567 & 2317 & 1268 & 1895 & 1956 & 2872 & 591 \\
\hline Maximun & 408 & 2574 & 2867 & 18,50 & 1040,82 & 1042,73 & 5345 & 0,97 \\
\hline Minimun & 239 & 240 & 244 & 15,82 & 932,80 & 856,38 & 136 & 0,23 \\
\hline Average & 335 & 738 & 867 & 17,27 & 1007,85 & 987,20 & 1512 & 0,63 \\
\hline $\mathrm{v}(\%)$ & 13 & 52 & 58 & 3,83 & 1,52 & 4,46 & 58 & 18,53 \\
\hline Range & 168 & 2333 & 2624 & 2,67 & 108,03 & 186,35 & 5209 & 0,74 \\
\hline
\end{tabular}

Legend. $n$ : number of measurements; v: coefficient of variation. The situation of the halls is indicated in figure 1. 


\section{Temperature of the rock}

Rock temperature is approximately between $1.0^{\circ} \mathrm{C}$ and $2.0^{\circ} \mathrm{C}$ lower than temperatures of air in the different halls, with a mean value of $17.27^{\circ} \mathrm{C}$ (Table 1 ). The yearly evolution presents the same wave trend than air temperature of the cave, with a range of variation of $2.67^{\circ} \mathrm{C}$ (Table 1 and Fig. 4A).

The opening of the cave also creates modifications in the rock temperature, although with smaller amplitudes than the air. In a day with a small number of visitors, the daily increases are about $0.02^{\circ} \mathrm{C}$ and in a day of high flux of visitors the daily increase is $0.15^{\circ} \mathrm{C}$ (Fig. $5 \mathrm{~B}$ ).

\section{Relative humidity of the cave air}

The average relative humidity is similar in the three monitoring points of the cave, with values between 78 and 83\% (Table 1). On an annual scale, the temporal evolution of relative humidity within the cave shows lower values during autumn and winter, and maximum values during summer (Fig. 4B). These changes in relative humidity are basically due to variations in the drip flow within the cave. Because vapour water saturation is raised during summer months, when rock temperature is lower than that of the cave air (Fig. 4A), process of condensation cannot be absolutely rejected.

Figure 5C shows daily increases in relative humidity of the air of 2-3\%, as a consequence of the water vapour exhaled by visitors (Carrasco et al. 1999).

\section{Carbon dioxide}

Within the cave, the concentration of $\mathrm{CO}_{2}$ in the air varies according to the season, coinciding with the temporal evolution of air temperature and relative humidity inside the cave (Fig. 4C). These variations are mainly due to natural factors such as seasonal fluctuations of the $\mathrm{CO}_{2}$ content in the soil (Atkinson, 1977; Troester and White, 1984); of drip water flow and rate of natural ventilation within the cave (Fig. 4D), but are also due to human factors (the $\mathrm{CO}_{2}$ produced by visitors to the cave). Thus, during summer, the $\mathrm{CO}_{2}$ concentration inside the cave reach its maximum value (above 2,500 ppm, table 1 and Figure 4), coinciding with (1) a lower index of natural ventilation (Fig. 4D), (2) a greater drip flow (which introduces water rich in $\mathrm{CO}_{2}$ from the soil) and (3) higher number of visitors. In winter, $\mathrm{CO}_{2}$ concentration inside the cave reach its minimum, similar to that measured in the external atmosphere, due to a more effective natural ventilation, reduced drip water flow (resulting in a lower input of $\mathrm{CO}_{2}$ into the cave) and lower number of visitors.

Each day, there is an increase in $\mathrm{CO}_{2}$ concentration during the opening hours and a decrease during closure, both at midday and during the night (Fig. 5D). During a day of few visitors, the minimum values, during the night, are $250 \mathrm{ppm}$ according to the natural concentration in the earth atmosphere, but can reach 400-450 ppm during the daily periods of visits. During days of major visitors, $\mathrm{CO}_{2}$ concentration can reach maximums of thousands of ppm (Fig. 5D).

One of the main factor that influence the $\mathrm{CO}_{2}$ concentration is the natural ventilation of the cave system. By way of Radon concentration measurements in the air of the cave (Cañete 1997; Dueñas et al. 1999) the index of ventilation was calculated. This index varies between $0.2 \mathrm{~m}^{3} / \mathrm{s}$ in spring-summer and $2.8 \mathrm{~m}^{3} / \mathrm{s}$ in autumn-winter, what indicates a higher renovation of the air during the latter period than the former one. This evidence is supported with the values of wind velocity (Fig. 4D). 


\section{ANTHROPIC IMPACT ON THE WATER}

\section{Monitoring points and analytical methodology}

Hydrochemical monitoring of two types of groundwater began in October 1991: the drip water inside the cave and the water of the phreatic zone. The first water was sampled at 10 points (Fig. 1B) until March 1993; but after a statistical study of the whole data (Andreo \& Carrasco 1993b; Carrasco \& Andreo 1993; Carrasco et al. 1995, 1996) the network was reduced to one point (number 3 in figure 1A). The second type of water was sampled in the Maro spring (point $\mathrm{M}$, figure 1A) and in a well used for water supply (point $\mathrm{W}$, figure 1A). The sampling periodicity has varied in the studied period: monthly, between 1991 and December 1993; fortnightly, between January 1994 and October 1995 and weekly from November 1995 to present time.

In any case, $\mathrm{pH}$, temperature and electrical conductivity were measured in the field. In laboratory, the alkalinity $\left(\mathrm{HCO}_{3}^{-}\right.$) was measured by volumetry with $\mathrm{H}_{2} \mathrm{SO}_{4}$ and $\mathrm{Ca}^{2+}$ and $\mathrm{Mg}^{2+}$ by complexometry with EDTA, the same day when sampled. Major components were analysed: $\mathrm{Cl}^{-}$ by argentometry, $\mathrm{SO}_{4}^{2-}$ by gravimetry, $\mathrm{SiO}_{2}$ and $\mathrm{NO}_{3}^{-}$by spectrophotometry, and $\mathrm{Na}^{+}$and $\mathrm{K}^{+}$by flame photometry. Analyses with balance errors over $5 \%$ were not considered.

\section{Human impact on the chemical quality of groundwater}

Table 2 shows a statistical summary of the results obtained from the hydrochemical monitoring. The Principal Component Analysis of figure 6 distinguish three groups of waters (Andreo \& Carrasco 1993b; Carrasco \& Andreo 1993).

The majority of the drip water (points 2 to 10 in figure $1 \mathrm{~B}$ and table 2) has low electrical conductivity values (between 392 and $531 \mu \mathrm{S} / \mathrm{cm}$ ), so low contents in the major components (group I in figure 6) and a Ca-Mg- $\mathrm{HCO}_{3}$ type. In a previous work, Romero et al. (1991) indicate that this water presents microbiological contamination, which rises in summer. Another
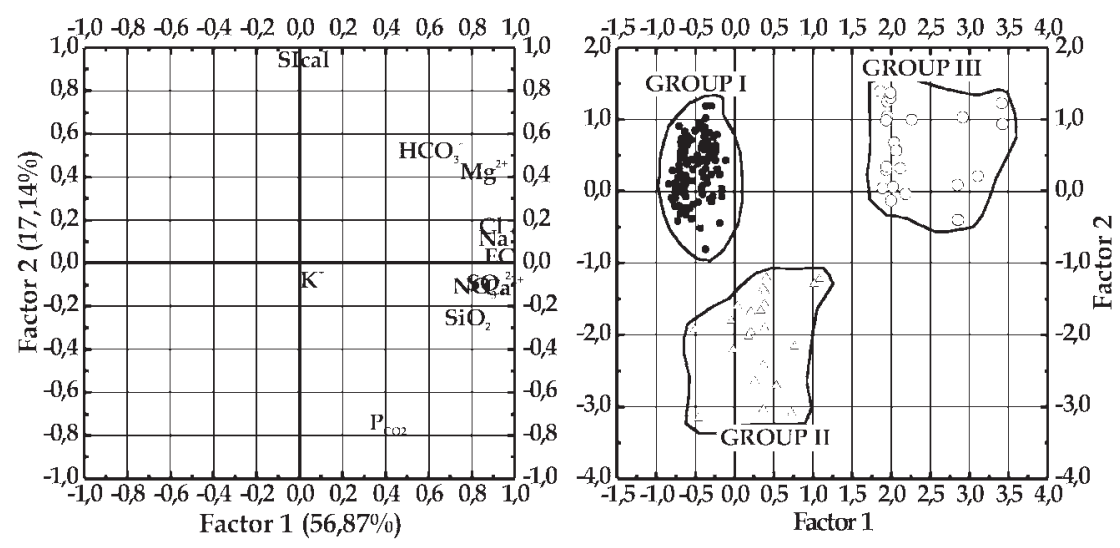

Fig. 6: Principal Component Analysis with hydrochemistry data of the monitoring network. Left: Loadings of 12 physical-chemical variables.

Right: plot of scores for Principal Components 1 and 2 (see more explanation in the text). 
anthropogenic impact related with the drip water and the lighting is the growing of green algae (Ruiz-Sanchez et al. 1991).

The samples taken from the phreatic zone of the aquifer (group II) have a $\mathrm{Ca}-\mathrm{HCO}_{3}-\mathrm{SO}_{4}$ type of water for point $\mathrm{M}$ and a $\mathrm{Ca}-\mathrm{Mg}-\mathrm{HCO}_{3}$ type for point $\mathrm{W}$ (figure 1 and table 2). The electrical conductivity is slightly higher than the group I, 648 at point $\mathrm{M}$ and $674 \mu \mathrm{S} / \mathrm{cm}$ at point $\mathrm{W}$.

Nevertheless the most mineralised water comes from point 1 in Hall A (group III in figure 6), which is $\mathrm{HCO}_{3}-\mathrm{SO}_{4} \mathrm{Ca}-\mathrm{Mg}$ type, and the electrical conductivity between 895 and $1453 \mu \mathrm{S} / \mathrm{cm}$, because of the higher content in all the components analysed. This water corresponds to the water pumped from the well (W) which is used for watering the gardens, passes through the anthropic soil and drips inside the cave. The concentration factor of the well water in the process of infiltration is approximately 1.5 for the electrical conductivity and carbonate parameters $\left(\mathrm{HCO}_{3}^{-}, \mathrm{Ca}^{2+}\right.$ and $\mathrm{Mg}^{2+}$ ), whereas this factor is superior to 2.0 for $\mathrm{Cl}^{-}$and $\mathrm{Na}^{+}$and reaches 3.2 in the $\mathrm{SO}_{4}^{2-}$ content. The flow towards the interior of the cave produces a reconcentration in all the major components, particularly in $\mathrm{SO}_{4}^{2-}(297 \mathrm{mg} / \mathrm{l}$ as mean value $), \mathrm{Cl}^{-}(84 \mathrm{mg} / \mathrm{l})$ and $\mathrm{Na}^{+}(33 \mathrm{mg} / \mathrm{l})$, which come both of rainfall and anthropic soil origin. In the vicinity of point 1 there are some other drip points, not considered here, that show the same hydrochemical features.

So the human intrusion in the Nerja Cave produces impacts on the natural quality of the groundwater, because of the anthropic activities in garden zones and in the services installed.

\section{Influence on the calco-carbonic parameters of the water}

The partial equilibrium pressure of $\mathrm{CO}_{2}\left(\mathrm{P}_{\mathrm{CO} 2}\right)$ and the saturation indexes for calcite (SIc) and dolomite (SId) were calculated from the obtained data (Table 2), using the program SOLUTEQ (Bakalowicz 1984).

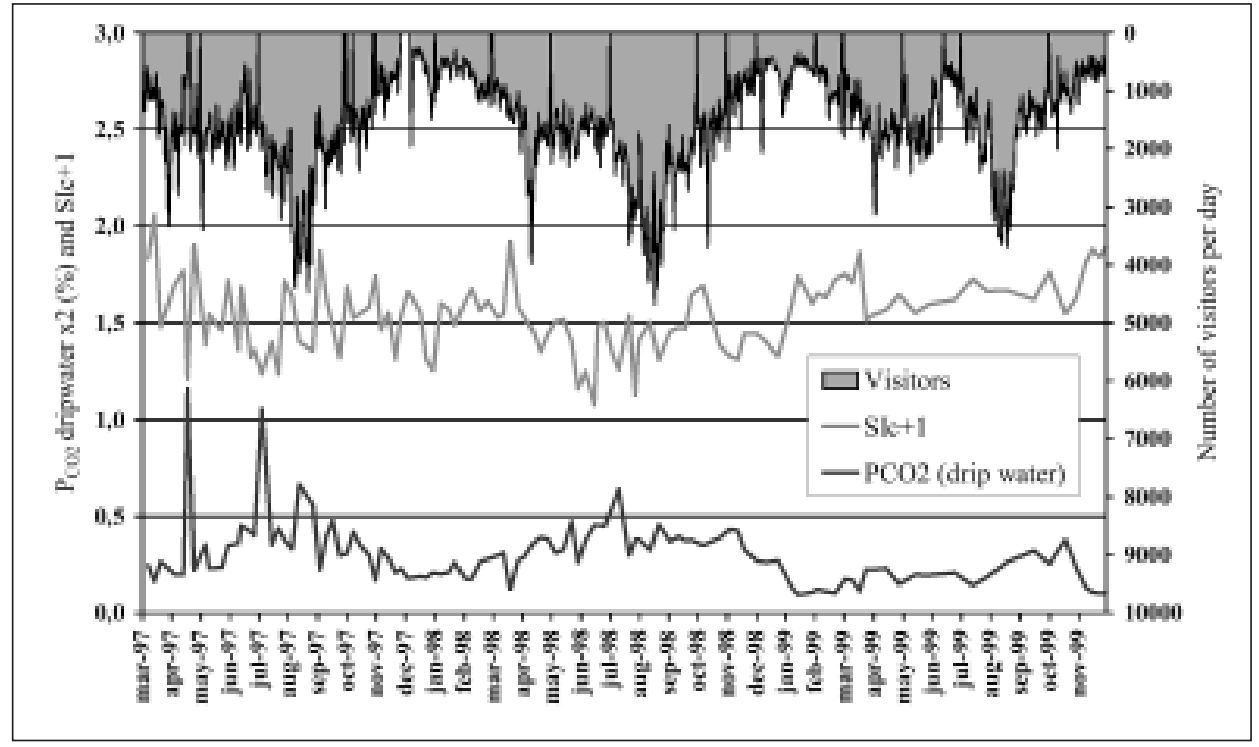

Fig. 7: Seasonal evolution of SIc and $P_{\mathrm{CO} 2}$ in the drip water of Nerja Cave. 
Normally the drip water is supersaturated with respect to calcite $(\mathrm{SIc}=0.60-0.95)$ and dolomite $(\mathrm{SId}=1.67-2.17)$ and presents $\mathrm{P}_{\mathrm{CO} 2}$ values varying $0.05-0.18 \times 10^{-2} \mathrm{~atm}$. Point 1 presents higher values in these parameters $\mathrm{SIc}=0.86, \mathrm{SId}=1.64, \mathrm{P}_{\mathrm{CO} 2}=0.43 \times 10^{-2} \mathrm{~atm}$, because it comes from the well and passes through the garden soil where a relatively important biological activity takes place, producing more $\mathrm{CO}_{2}$ than in the soil which exists above the rest of the cavity.

The seasonal evolution of $\mathrm{P}_{\mathrm{CO} 2}$ in the drip water (Fig. 7) shows, in general, low values in winter and high values in summer. This temporal evolution of the $\mathrm{P}_{\mathrm{CO} 2}$ in water is related to natural factors: the rainfall that infiltrates dissolves the $\mathrm{CO}_{2}$ produced in the soil by biological activity and is transported towards the cave. Although $\mathrm{P}_{\mathrm{CO} 2}$ in water has a natural origin, processes in which visitors are involved might not be absolutely neglected, because in summer there are more visitors, introducing more $\mathrm{CO}_{2}$ into the atmosphere of the cave. The increasing in $\mathrm{P}_{\mathrm{CO} 2}$ produces a disminution in the SIc values and an alteration of the speleothems may occur.

\section{CONCLUSIONS}

In the caves open to the public, such as the Nerja Cave, the considerable number of visitors produces an impact on the environmental parameters inside the cave and on the hydrochemical characteristics of the groundwater.

Main daily changes in environmental parameters are the following: cave air temperature rises to $0.2^{\circ} \mathrm{C}$ per 1,000 visitors, temperature of the rock rises between $0.02^{\circ} \mathrm{C}$ and $0.15^{\circ} \mathrm{C}$, relative air humidity increases to $2-3 \%$, nearly reaching saturation on some summer days and the carbon dioxide concentration can reach values 10 times greater than the natural mean value.

The majority of drip water has low mineralisation, it is $\mathrm{HCO}_{3} \mathrm{Mg}$-Ca type. In addition, the $\mathrm{P}_{\mathrm{CO} 2}$ of the water drip increases in summer. This $\mathrm{P}_{\mathrm{CO} 2}$ increase produces a disminution in the SIc values and alteration of the speleothems may occur.

Condensation processes might occur, because during some summer days the relative humidity in the cave atmosphere reaches $100 \%$, which could originate water unsaturated in calcite able to dissolve $\mathrm{CaCO}_{3}$ from the spelothems. Moreover, in sites where drip water and light coexist, green algae appears.

In the areas inside the cave but closer to the entrance, the drip water sampled is very mineralised and $\mathrm{HCO}_{3}-\mathrm{SO}_{4} \mathrm{Ca}-\mathrm{Mg}$ type, because it is water pumped from a well, used for watering the garden. So this drip water has high concentration in $\mathrm{SO}_{4}^{2-}, \mathrm{Cl}^{-}$and $\mathrm{Na}^{+}$, originated from dissolution of these components in the anthropic soil and reconcentration of the rainfall

\section{ACKNOWLEDGEMENTS}

To the Nerja Cave Foundation for its financial assistance to carry out this study. This study is also a contribution of the Research Group RNM-308 of the Andalusian Government to the Project IGCP 448 of UNESCO and Pb98-1397. 


\section{REFERENCES}

Andreo, B. \& Carrasco, F., 1993a: Estudio hidrogeológico del entorno de la Cueva de Nerja. In: Geología de la Cueva de Nerja (Carrasco F. ed). Trabajos sobre la Cueva de Nerja, 3: 163-187.

Andreo, B. \& Carrasco, F., 1993b: Estudio geoquímico de las aguas de infiltración de la Cueva de Nerja. In: Geología de la Cueva de Nerja (Carrasco F. ed). Trabajos sobre la Cueva de Nerja, 3: 299-328.

Andreo, B. \& Carrasco, F. \& Sanz de Galdeano, C., 1993: Estudio geológico del entorno de la Cueva de Nerja. In: Geología de la Cueva de Nerja (Carrasco F. ed). Trabajos sobre la Cueva de Nerja, 3: 25-50.

Andrieux, C., 1988: Influence del'homme sur l'environnement climatique souterrain. Actes des Journées Trombes, Moulis, Ariège, 1: 96-122.

Atkinson, T.C., 1977: Carbon dioxide in the atmosphere of the unsaturated zone: an important control of groundwater hardness in limestones. J. Hydrol., 35: 111-123.

Bakalowicz, M., 1984: Water chemistry of some karst environments in Norway. Norks. Geogr. Tidsskr 38: 209-214.

Benavente, J. \& Almécija, C., 1993: Estudio geomorfológico del entorno de la Cueva de Nerja. In: Geología de la Cueva de Nerja (Carrasco F. ed). Trabajos sobre la Cueva de Nerja, 3: 119-158.

Bertolani, M. \& Cigna, A. \& Maccio, S. \& Morbidelli, L. \& Sighnolfi, G., 1991: The kasrt system "Grotta Grande del Vento-Grotta del Fuime" and the conservation of its environment. Proceedings of the International Conference on environmental changes in karst areas, Univ. Padova, 13: 289-298.

Cañete, S., 1997: Concentraciones en Radón e intercambio de aire en la Cueva de Nerja. Tesis de Licenciatura, Univ. Málaga, 84 p, unpublished.

Carrasco, F. \& Andreo, B., 1993: Características de las aguas de infiltración de la Cueva de Nerja (Málaga). Geogaceta, 14: 9-12.

Carrasco, F. \& Andreo, B. \& Benavente, J. \& Vadillo, I., 1995: Chemistry of the Nerja Cave system (Andalusia, Spain). Cave and Karst Science, 21 (2): 27-32.

Carrasco, F. \& Andreo, B. \& Liñán, C. \& Vadillo, I., 1996: Consideraciones sobre el funcionamiento hidrogeológico del entorno de la Cueva de Nerja (provincia de Málaga). Jornadas sobre Recursos Hídricos en regiones kársticas, Vitoria, 249-263.

Carrasco, F. \& Andreo, B. \& Vadillo, I. \& Durán, J.J. \& Liñán, C., 1999: El medio ambiente subterráneo de la Cueva de Nerja (Málaga). Modificaciones antrópicas. In: The scientific study of karstic cavities as a contribution to geological knowledge (Andreo B., Carrasco F. and Durán J.J., eds.), 323-334.

Cigna, A., 1993: Environmental management of tourist caves: the examples of Grotta di Castellana and Grotta Grande del Vento, Italy. ${ }^{E}$ nvironmental Geol., 21: 173-180.

Dueñas C. \& Fernández M.C. \& Cañete S. \& Carretero J. \& Liger E., 1999: ${ }^{222}$ Rn concentrations, natural flow rate and the radiation exposure levels in the Nerja Cave. Atmospheric Environment, 33: 501-510.

Durán, J.J. \& Grün, R. \& Ford, D., 1993: Dataciones geocronológicas (métodos ESR y series de Uranio) en la Cueva de Nerja. Implicaciones evolutivas, paleoclimáticas y neotectónicas. 
In: Geología de la Cueva de Nerja (Carrasco F. ed). Trabajos sobre la Cueva de Nerja, 3: 233-248.

Fernández, P.L. \& Gutiérrez, I. \& Quindós, L.S. \& Soto, J. \& Villar, E., 1986: Natural ventilation of the Paintings Room in the Altamira Cave. Nature, 321: 586-588.

Huppert, G. \& Burri, E. \& Forti, P. \& Cigna, A., 1993: Effects of tourist development on caves and karst. Catena supplement, 25: 251-268.

IGME 1983: Informe $n^{\circ} 10$ sobre el Sistema Acuífero n 41: calizas y dolomías triásicas de la Sierra Almijara-Sierra de Lújar. Memoria y anejos.

Liñán C. \& Andreo B. \& Carrasco F. \& Vadillo I., 1999: Hidrodinámica e hidroquímica de las aguas de goteo de la Cueva de Nerja. In: The scientific study of karstic cavities as a contribution to geological knowledge (Andreo B., Carrasco F. and Durán J.J, eds.), 393-402.

Liñán C. \& Andreo, B. \& Carrasco, F., 2000: Caracterización hidrodinámica e hidroquímica del manantial de Maro (Sierra Almijara, provincia de Málaga). Geogaceta, 27: 95-98.

Mangin, A. \& Bakalowicz, M. \& Andrieux, C. \& D’Hulst, D. \& Daffis, J., 1991: Etude de l' environnement souterrain de la Grotte du Pech-Merle Cabbrerets (Lot). Report du Centre National de la Reserche Scientifique, 45 p.

Mangin, A. \& D’Hulst, D., 1995: Fréquentation des grottes touristiques et conservation. Méthode d'approche pour en étudier les effets et proposer une réglementation. Simposio Internazionale Grotte turistiche e Monitoraggio Ambientale, Stazione Scient, Bossea, Italia, 117-145.

Mangin, A. \& Bourges, F. \& D’Hulst, D., 1999: La conservation des grottes ornées: un problème de stabilité d'un système naturel (l'exemple de la grotte préhistorique de Gargas, Pyrénées françaises). C.R. Acad. Sci. Paris, 329: 295-301.

Marion, J.B. \& Homyak, W.F., 1985: General Physics with Bioscience Essay. John Wiley and Sons.

Pulido-Bosch, A. \& Martin-Rosales, W. \& López-Chicano, M. \& Rodríguez-Navarro, C.M. \& Vallejos, A., 1997: Human impact in a tourist karstic cave (Aracena, Spain). Environmental Geol., 31: 142-149.

Romero, P. \& Borrego, J.J. \& De Vicente, A. \& Moriñigo, A. \& Martínez-Manzanares, E. \& Arrabal, F. \& Florido, J.A. \& Avilés, M. \& Cornax, R. \& Codina, J.C. \& Arcos, M.L., 1991: Estudio microbiológico y químico de las aguas de la Cueva de Nerja (Málaga). In: Investigación biológica y edafológica de la Cueva de Nerja (Marín F. \& Carrasco F., eds). Trabajos sobre la Cueva de Nerja, 2: 45-109.

Ruiz Sánchez, I. \& Marín-Girón, F. \& Ojeda, F. \& Marín-Olalla, F. \& Berros, J. \& Marín- Olalla, E., 1991: Estudio macroscópico “in situ” y microscópico-ecológico de pequeñas zonas de flora verde (algas verdes y verdeazuladas) del interior de la Cueva de Nerja. In: Investigación Biológica y edafológica de la Cueva de Nerja (Marín F. \& Carrasco F., eds). Trabajos sobre la Cueva de Nerja, 2: 113-125.

Sanz de Galdeano, C., 1986: Structure et stratigraphie du secteur oriental de la Sierra Almijara (Zone Alpujárride, Cordilléres Bétiques). Estudios Geol., 42: 281-289.

SGOP 1991: Estudio hidrogeológico de las Sierras Tejeda, Almijara y Guájares (Málaga y Granada). Technical report.

Troester J.M. \& White, W.B., 1984: Seasonal fluctuations in the carbon dioxide partial pressure in a cave atmosphere. Water Resources Research, 20: 153-156.

Trombe F., 1952: Traité de Speleologie. Payot. París. 


\section{PREGLED OKOLJSKIH PARAMETROV PRI VODENJU IN VAROVANJU JAME NERJA (MÁLAGA, ŠPANIJA)}

\section{Povzetek}

Jama Nerja je v južni Španiji, v Andaluziji, 50 km vzhodno od Málage in manj kot kilometer od morja. Jama je razdeljena na dva dela: turistični obsega tretjino jame v vhodnem delu, neturistični del pa obsega ostali dve tretjini v notranjem delu, ki ga le občasno obišče skupina raziskovalcev ali speleologov. Jama je skoraj vodoravna, z volumnom okoli $300.000 \mathrm{~m}^{3}$. Največji rovi so v smeri S - J in N3 5E, kar sovpada z glavnimi smermi razpok.

Z geološkega vidika leži Nerja v Betijskih Kordiljerah, v kompleksu Alpujarride, v zgornjem delu enote Almijara. To enoto sestavljata paleozojska metapelitska formacija v spodnjem delu, nad njo pa karbonatna formacija. Sama jama je razvita v dolomitnih marmorjih te zadnje formacije. Zaradi neotektonske aktivnosti je jama danes v nezasičeni coni vodonosnika.

Klima tega področja je tipična sredozemska, s srednjo letno temperaturo $16,5^{\circ} \mathrm{C}$, v razponu med $11,4{ }^{\circ} \mathrm{C}$ januarja in $24{ }^{\circ} \mathrm{C}$ avgusta. Srednja letna količina padavin je $500 \mathrm{~mm}$, ki pa so neenakomerno razporejene, $\mathrm{z}$ dežjem od novembra do januarja in suhim poletjem.

Jama je bila odkrita 1959 in naslednjega leta odprta za obisk. Od takrat si je jamo ogladalo veliko število obiskovalcev, preko 500.000 letno. Tak obisk seveda vpliva na jamo: spreminjajo se klimatski pokazatelji (temperatura, vlažnost in količina $\mathrm{CO}_{2}$ ), onesnaženje in spremembe fizikalno-kemijskih lastnosti vode in spremembe na kamnini. Kjer sta svetloba in voda, se pojavlja mikroflora (predvsem alge). Zaradi tega so potrebne obsežne raziskave pokazateljev okolja ter fizičnih in kemičnih lastnosti vode, tako v jami kot tudi na površju.

Da bi ugotovili vpliv turističnega obiska na podzemeljsko okolje, je bila 1993 vzpostavljena opazovalna mreža (monitoring), ki naj bi spremljala različne pokazatelje (temperaturo zraka in skale, relativno vlažnost, koncentracijo $\mathrm{CO}_{2}$, zračni pritisk in hitrost vetra) v enournih presledkih. Od 1991 je uvedeno spremljanje hidrokemičnih pokazateljev v kapljajoči vodi in v iztoku iz karbonatnega vodonosnika. To zvezno spremljanje fizikalno-kemijskih lastnosti v kapljajoči vodi, njene dnevne količine, kot tudi temperature in vlažnosti zraka, koncentracije $\mathrm{CO}_{2}$ in temperature skale kažejo na vpliv človeka.

Dnevne spremembe okoljskih pokazateljev so: na vsakih 1000 obiskovalcev se temperatura zraka zviša za $0,2{ }^{\circ} \mathrm{C}$, temperatura skale zraste od $0,02{ }^{\circ} \mathrm{C}$ do $0,15^{\circ} \mathrm{C}$, relativna vlažnost zraka za 2-3 \% in v poletnih dneh skoraj doseže zasičenje in koncentracija ogljikovega dioksida lahko doseže desetkrat večje vrednosti od naravnega povprečka.

Največji del kapljajoče vode ima zelo nizko mineralizacijo tipa $\mathrm{HCO}_{3}^{-} \mathrm{Mg}^{2+}, \mathrm{Ca}^{2+}$ in $\mathrm{kaže}$ mikrobiološko kontaminacijo, posebno poleti, ko je največ obiskovalcev. Povrhu se v kapljajoči vodi kažejo spremembe $P\left(\mathrm{CO}_{2}\right)$, in sicer naraščanje poleti, kar sovpada z večjim obiskom, in padanje indeksa zasičenosti s karbonatnimi minerali, zaradi česar lahko pride do razpadanja kapnikov. Lahko pride tudi do procesa kondenzacije, saj je poleti temperatura skale nižja od jamskega zraka, relativna vlažnost pa doseže $100 \%$, kar spet lahko da vodo, nezasičeno s kalcitom in torej sposobno razgrajevati kapnike.

$\mathrm{V}$ zunanjem coni tistega dela jame, ki je namenjen obisku, kažejo vzorci kapljajoče vode visoko mineralizacijo tipa $\mathrm{HCO}_{3}^{-}, \mathrm{SO}_{4}^{2-}, \mathrm{Ca}^{2+}, \mathrm{Mg}^{2+}$, saj gre za vodo, ki jo črpajo iz vodnjaka in uporabljajo kot pitno vodo in za namakanje. Ta kapljajoča voda ima torej visoke koncentracije $\mathrm{SO}^{2-}, \mathrm{Cl}^{-}$in $\mathrm{Na}^{+}$, ki jih izpira iz vrtnih prsti. 